\title{
Levels of the absolute in Husserl
}

\author{
Bence Peter Marosan ${ }^{1,2}$
}

Accepted: 13 October 2021 / Published online: 8 November 2021

(C) The Author(s) 2021

\begin{abstract}
Edmund Husserl's ultimate aim was to give an overall philosophical explanation of the totality of Being. In this endeavour, the term "absolute" was crucial for him. In this paper, I aim to clarify the most important ways in which Husserl used this notion. I attempt to show that, despite his rather divergent usages, eventually three fundamental meanings and coordinated levels of the "absolute" can be differentiated in his thought: the epistemological (absolute evidence and ego), the ontological (intersubjectivity), and the theological or metaphysical level (God). According to Husserl, we can approach this ultimate level of the Absolute, through the method of phenomenological construction. A closer reading of Husserl's texts shows that his conception of the absolute was astonishingly modern. The main features of the conception-on all three levels-were non-foundationalism, contextualism, openness, and circularity. Each level mutually founds and determines the others. It is a nonfoundational Absolute, the moments of which constitute an organic and open totality which is essentially processual. In my interpretation, this theory opens a fruitful working area, which has enormous philosophical potential and is surprisingly up-to-date.
\end{abstract}

Keywords Edmund Husserl · Phenomenological metaphysics · Phenomenological construction · Non-foundational absolute $\cdot$ God $\cdot$ Intersubjectivity $\cdot$ Transcendental ego

Dedicated to the memory of Professor Rudolf Boehm (1927-2019).

Bence Peter Marosan

Marosan.Bencepeter@uni-bge.hu

1 Faculty of International Management and Business, Budapest Business School, Diósy Lajos utca 22-24, Budapest 1165, Hungary

2 Faculty of Humanities and Social Sciences, Pázmány Péter Catholic University, Egyetem u. 1., Piliscsaba 2087, Hungary 


\section{Introduction ${ }^{1}$}

In Edmund Husserl's phenomenology, the problem of the Absolute counts as a central question. Throughout his entire career, he attempted to reach the level of the absolute, a sort of unquestionable, unconditional givenness. In Logical Investigations (1900/01), he spoke about the idea of absolute truth, knowledge, and evidence. In his work On the Phenomenology of the Consciousness of Internal Time (1893-1917), he wrote about "absolute subjectivity," "absolute time-constituting consciousness." In his Lectures on Ethics and Value Theory (1908-1914), he was dealing with "absolute values." In the Ideas Pertaining to a Pure Phenomenology and to a Phenomenological Philosophy (1913), the concept of "absolute consciousness" is introduced as a decisive point of orientation for phenomenological analyses and descriptions. ${ }^{2}$ Many authors, such as Richard Rorty and Husserl's Heideggerian critics, understood Husserl's perpetual references to such absolute points of orientation or to an absolute level of cognition and Being, which should be attained in an essentially foundationalist project. ${ }^{3}$ I argued elsewhere that Husserl can be interpreted in a non-foundationalist way, even if his references to the concept of absolute are considered either as an adjective (e.g. "absolute consciousness," "absolute givenness," "absolute truth," etc.) or a noun ("the Absolute," "das Absolute," as the ultimate aspect of reality). ${ }^{4}$ In my interpretation, after a more careful, attentive analysis, the quite paradoxical concept of "non-foundationalist absolute" can be identified in Husserl's work. ${ }^{5}$

\footnotetext{
1 This paper was supported by the János Bolyai Research Scholarship of the Hungarian Academy of Sciences (project: BO/00421/18/2).

I would like to express my gratitude to all who contributed to this paper. Amongst others I would like to say thank you to Flóra Besze, Vittorio de Palma, George Heffernan, Nam-In Lee, David Morgan, Jessie Stanier, Tünde Vajda and Jeffrey Yoshimi.

2 Ideas Pertaining to a Pure Phenomenology and to a Phenomenological Philosophy-hereafter "Ideas." Husserl (1976). Written in 1912, its first book was originally published in 1913, the second and third only posthumously.

3 Rorty (1979). Cf. also: Bernstein (1983).

4 Marosan (2020).

5 In the last three decades, intense debates took place that questioned the view Husserl was a foundationalist. As Dagfinn Føllesdal mentions in his 1988 article, at that time it was a "universally accepted view" that Husserl was a foundationalist (1988, p. 115). He was one of the first authors who rejected this interpretation.
}

Later, in the 1990s and 2000s many Husserl-scholars adopted the view that Husserl was a non-foundationalist philosopher; such as: Drummond (1990), Zahavi (2003, p. 67). Walter Hopp criticized Drummond's conception of Husserl as an "internalist non-foundationalist," and argued for the view that Husserl was an "externalist non-foundationalist" (2008).

Philipp Berghofer recently offered an approach, according to which Husserl could be interpreted as a "moderate foundationalist." He emphasizes that one could distinguish between three main different forms of foundationalism: "Strong foundationalism: Basic beliefs must be infallible. Moderate foundationalism: Basic beliefs can be fallible (but are adequately justified on their own). Weak foundationalism: Basic beliefs have some degree of justification, but they are not adequately justified on their own. In order to be adequately justified, even basic beliefs need to cohere with other beliefs" (2018, p. 4).

I would like to make two comments on Berghofer's interpretation. First, I am arguing against the view that Husserl was a strong foundationalist. Second, I believe that Husserl made certain statements on evidence and truth that exceed even the limits of "moderate foundationalism" and which point to a radically contextualist notion of evidence and truth. Namely, if we want to disclose the ultimate nature of reality 
In this study, I argue that Husserl's various notions of the absolute stand in a particular relationship with each other, making up a complex and dynamic conceptual network. I will attempt to show that the precise structure of this network and theoretical framework was important-even central-to him. The different concepts of the absolute in his writings referred to different levels of one and the same Absolute: the ultimate aspect of reality. In my opinion, we can identify three main levels of Absolute in Husserl's works: (1) the level of "absolute consciousness;" (2) of "transcendental intersubjectivity;" and (3) God. In the main parts of the article, I aim to shed light on the particular relationship between these three levels. ${ }^{6}$

I will argue that these notions at each of the three levels correspond to a relatively independent field of phenomenological investigation, calling for a particular methodological approach. For Husserl, absolute consciousness is the epistemological absolute, transcendental intersubjectivity is the ontological absolute, and God is the theological or metaphysical absolute. The moments and levels of Absolute, under the level of God, imply the rather paradoxical term "relative absolute."

In the last section (III) and Conclusion, I attempt to show why Husserl's notion of the Absolute is a fairly modern and up-to-date conception, and one that could be put to good use in contemporary philosophical research. Essentially temporal and processual, it is a non-foundationalist absolute and is characterized by radical openness. This concept of Absolute could be a helpful point of orientation for phenomenological analyses of experience as well as for scientifically grounded metaphysical and theological attempts.

\section{Absolute consciousness: the epistemological absolute}

One of Husserl's most important aims was to secure the absolute foundation of cognition (Erkenntnis) and epistemological investigations. In this project, the notion of evidence and, in particular, absolute (ultimate) evidence played a crucial role. For Husserl, absolute evidence was strongly connected to "apodictic" (inevitable, incorrigible, infallible) evidence. Evidence, according to him, was an original mode of experience, in which an object or a fact is given directly, "in the flesh" ("leibhaftig"). ${ }^{7}$ In Husserl's epistemology, this absolute evidence-as absolute givenness of the object or fact-serves as a fundamental point of orientation in the justification of philosophical or scientific theories. In the end, however, according to Husserl, all

\footnotetext{
Footnote 5 (continued)

("the Absolute" as a noun), then we must perpetually attempt to disclose the infinitely open network of evidence that grants us access to that level of reality.

${ }^{6}$ Here we should mention the 1959 study of Rudolf Boehm, who also spoke about the different levels of the Absolute - and he also highlighted three main levels. First, absolute evidence or givenness as the accomplishment of absolute consciousness. Second, there is the absolute consciousness itself. Third, there is God as the ultimate Absolute. The former-for a more accurate consideration-always proves to be a dependent moment of the latter. This idea-according to which the lower level is a dependent moment of the higher-will play a decisive role in our present study also.
}

7 See e.g.: Heffernan (1999, 2021), Lee (2007). 
evidence is the accomplishment of an individual consciousness, and every evidently presented object or fact is given to this consciousness. In Husserl's view, one's own individual consciousness is the ultimate source of all meaning and validity, to which every constituted thing is related as objective and thus relative. ${ }^{8}$ For this reason, he calls this consciousness "absolute" because it is an absolute epistemological foundation and the final point of orientation for all philosophical and scientific research.

In the following parts, we can see that, for Husserl, the different levels of the Absolute do not stand in a strictly hierarchical relationship with each other. For a closer analysis, their relationship proves to be circular and dynamic; so it cannot be treated in terms of classical foundationalism. ${ }^{9}$ In this present part of the essay, we will focus on the relationship between absolute evidence and consciousness.

\subsection{Absolute evidence}

Ever since Husserl achieved the "breakthrough of phenomenology" in the seminal Logical Investigations, right until his final research manuscripts, he attempted to reach and secure the ultimate foundations of knowledge in general, and scientific and philosophical knowledge in particular. In this enterprise, the notions of evidence and truth had central importance for him. He was especially interested in the quest to find a form of evidence that could resist every possible form of scepticism; but he fundamentally transformed this initially Cartesian endeavour. In Logical Investigations, Husserl mostly focused on the philosophical foundations of everyday and scientific knowledge. When he "discovered" the method of phenomenological reduction around 1906/07, he managed to widen the scope of phenomenology in order to embrace all philosophical questions, including ethics, aesthetics, metaphysics, philosophy of history, etc.

Evidence, as already mentioned, is an original mode of experience for Husserl. It is connected to perception or intuition (Anschauung). According to him, in perception or intuition something is given in different modes or grades of evidence. He emphasized that evidence is not a feeling, a psychological feature of certain experiences, but a characteristic of evidently presenting acts ${ }^{10}$ In Logical Investigations, it was a crucial matter for him to conduct the structural analysis of different, fundamental types of perception (sensible and categorial), because they served as the ultimate foundation of all knowledge. In Ideas, he formulated his famous "principle of all principles," according to which the ultimate source of all legitimate knowledge is originally giving intuition. ${ }^{11}$

\footnotetext{
8 In Husserl's phenomenology "constitution" means to unfold or disclose (Erschließen) things according to a priori laws. It is an a priori, necessary way of bestowing sense to the phenomena. Cf. Sokolowski (1970).

9 Regarding the idea of circular or reciprocal foundation in Husserl see: Steinbock (1995, p. 11).

${ }^{10}$ Cf. Heffernan $(1999,2021)$.

11 Husserl (1976, p. 51).
} 
When Husserl started to elaborate his complex methodology of phenomenological reductions in 1906/07, one of the most important aims of such reductions, and the transcendental turn connected with them, was to render his theory of evidence more precise, and to reach the sphere of absolute givenness. ${ }^{12}$ Phenomenological reductions made it possible to articulate the idea of the phenomenological attitude (Einstellung), and to take up and maintain this position. In Husserl's view, the phenomenological attitude displays the most radical form of evidence and the sphere of ultimate givenness: transcendental consciousness, which is the absolute source of all meaning, validity and experience. The properly performed phenomenological reflection is characterized by absolute evidence and its final object is transcendental consciousness itself.

In Ideas, Husserl defined four fundamental types of evidence through a twofold juxtaposition: adequate-inadequate and apodictic-assertoric evidence. ${ }^{13}$ Adequacy means that there is no unfulfilled intention in an evidently presenting complex act, or that the presented object cannot be given in a more complete way than it is. It also refers to the perfect coincidence (Deckung) of empty and fulfilling intention. Apodicticity on the other hand refers to the epistemic or modal status of the given, and that its givenness is inevitable and cannot be given other than it actually is. In this period, Husserl connects adequacy and apodicticity to the idea of absolute givenness or evidence. $^{14}$

Husserl's distinction between transcendent and immanent perception is also crucial in this regard. ${ }^{15}$ The objects of transcendent perception, the entities of the material world, could only be given in an inadequate, incomplete and non-apodictic way. The phenomena of immanent perception-experiences themselves and their relations-could be given in an adequate and apodictic manner. But, according to Husserl, perception need not only be individual, it could also be general. In his opinion, we are able to see general objects and structures in the strict sense of the word. Husserl calls this - amongst others_- "seeing of essences" or "eidetic intuition." He thought, at least in Ideas, that the essences of consciousness could be given adequately and apodictically. Later his concept of adequate evidence changed.

The most important tool of phenomenological research, according to Husserl, is phenomenological reflection, which, according to Klaus Held's fitting expression, is "thinking perception" ("denkende Wahrnehmung”), through which we can experience the attributes and structures of consciousness itself, and document them in a methodologically elaborate and, strictly scientific fashion. ${ }^{16}$

\footnotetext{
12 Husserl (1985).

13 Husserl (1976, pp. 317-321).

14 Heffernan refers to this conception of evidence by the notion of "triple-A" (absolute, adequate and apodictic evidence) (2009).

15 Terminology of the Ideas. In Logical investigations, he used the terms "external" and "internal" perception. In Ideas, however, he considered these expressions as inadequate and potentially misleading; therefore, he uses here and thereafter the words "immanent" and "transcendent" perception. Husserl (1976, p. 78).

16 Held (1966, p. 23).
} 
By the time he was writing Cartesian meditations (1929) at the latest, Husserl's interpretation of adequate evidence changed. In this work, and after it, Husserl conceived of this type of evidence as a guiding ideal of philosophical research, which in many cases cannot actually be reached. ${ }^{17}$ While apodicticity can be reached through transcendental reflection, adequacy cannot necessarily be attained. Throughout Husserl's lifework, the contextual and horizontal character of evidence became more and more emphatic; in fact, it became the dominant feature of his understanding of evidence. This is supposed to mean that, in the case of a properly purified and reflected experience or essence of experience, there is always an apodictic core to this reflection, which can never be modified. But new insights and findings shed new light on earlier ones, and partially_or even at crucial points-reinterpret them. The horizon of philosophical and scientific research is always open.

\subsection{Absolute consciousness and absolute ego}

In Husserl's opinion, the ultimate source of every intuition, perception, knowledge, sense-bestowing act, etc., is consciousness. Every act is a subjective performance of consciousness; all evidence is related to this sphere. From 1906/07 onwards, he started to systematically elaborate a sort of "transcendental idealism," with the idea of "absolute consciousness" at its centre, and also "absolute ego." ${ }^{18}$ In this period, he spoke about "absolute consciousness," "absolute subjectivity," as an ultimate source of every particular subjective performance and achievement. ${ }^{19}$ The first systematic, detailed and coherent elaboration of his conception of "pure" or "transcendental" consciousness is found in Ideas, in which Husserl also uses the term "absolute consciousness." 20 For him, pure or transcendental consciousness is absolute, inasmuch as its being is absolute; it is absolute being. ${ }^{21}$

Consciousness is absolute being, because every transcendent, every constituted being is relative to the being of consciousness. However, to Husserl, this did not mean that without consciousness there is no transcendent or empirical reality. Husserl labels that latter position-Berkeley's theory of esse est percipi-as a paradoxical, nonsensical idealism, and explicitly rejects that approach. ${ }^{22}$ Rather than its mere existence, external empirical reality owes to consciousness only the meaning and validity of transcendent being. It means that consciousness does not create the very being of transcendent, empirical reality in the literal sense. It rather discloses it; and it only constitutes the meaning or validity of "being transcendent," "being independent" of consciousness. ${ }^{23}$

\footnotetext{
17 Husserl (1973a, p.55f).

18 Husserl (2003, p.33).

19 On the Phenomenology of the Consciousness of Internal Time. Husserl (1969, pp.74f). Editor's note (Rudolf Boehm): the text of $\S \S 35-39$ is based on a draft that probably did not originate before the end of 1911 (p. 74).

${ }^{20}$ Husserl (1976, p.160).

21 Husserl (1976, pp.91-94).

22 Husserl (1976, p.120).

23 To this see also: Zahavi (2010).
} 
After Husserl's transcendental turn, he started to characterize his position as "transcendental idealism." It is easy to misunderstand this term; for some it might imply that Husserl embraced a classical, traditional, idealist metaphysics-whereas he, in fact, never did. For him, "transcendental idealism" meant treating consciousness as the ultimate constitutive source of every meaning, value and validity. ${ }^{24}$ When he began to systematically elaborate this conception around 1906/07, he started to purify the field of consciousness from everything empirical, conceiving it as a pure, non-empirical sphere of phenomena. Until 1908, Husserl grasped the consciousness as a pure egoless field. ${ }^{25}$ In 1908, a fundamental change took place in Husserl's thinking in this respect; in his research manuscripts, he started to speak of "absolute consciousness," which was organized, structured and centralized by an "absolute ego." ${ }^{26} \mathrm{He}$ began to discover the transcendental and purely phenomenological aspect of ego and, conversely, the egological aspect of pure consciousness.

"Absolute" ego and consciousness appeared in the terminology of Ideas mostly as "pure" ego and consciousness, and Husserl attempted to clarify their relationship and describe their structure systematically for the first time in that book. The "absolute" or "pure" ego appears as a centre for conscious experiences and acts, which organizes the life of consciousness. It is, as it were, a "background" transcendence to immanent, pure consciousness- "background" transcendence, insofar as the ego is somehow at the background of conscious functioning. At a certain point in Ideas I, he even considers the possibility of "exclusion ("Ausschaltung") of the pure ego." He says, "Because of the immediately essential role played by this transcendence in the case of any cogitation, we must not undertake its exclusion; though in many investigations the questions concerning the pure Ego can remain in suspenso." ${ }^{27}$ In later parts of the work, however, especially in Ideas II, he attributes an absolutely apodictic givenness to the pure ego, which cannot be disregarded in concrete phenomenological investigations. Consciousness is nothing other than the functioning of the pure ego. It is the relationship between subject and constituted object.

In Ideas I, the pure ego appears just as an abstract, logical pole. It is a completely "empty" point of relation of acts and experiences. As Husserl said, this ego does not have any "explicatable" content, "any inner hidden richness." 28 In this period, and this phase of his philosophical development, he conceived the transcendental ego as a purely formal entity. In the second book of Ideas, the personal, monadic ego is a constituted entity, right there outside the world. However, one could raise the question even with regard to this conception of the transcendental ego: if every pure ego is identical in this formal respect, if they are structurally and internally identical, that is to say, if all are "empty," how could they constitute themselves and their environment differently?

\footnotetext{
24 See: Moran (2003).

${ }^{25}$ Husserl (1950, 1985). Cf. also: Taguchi (2006, pp. 33-35).

26 Husserl (2003, pp.31-33).

27 Husserl (1983, p. 133).

28 Husserl (1976, p.179) (1952, pp.104f).
} 
This question and the "discovery" of the genetic phenomenological method around 1916/17 in combination led Husserl to a substantial revision of his earlier conception of transcendental ego in the early $1920 \mathrm{~s} .{ }^{29} \mathrm{He}$ recognized that this pure, formal ego is just an abstract moment in the fully concrete transcendental ego, which is a personal, historical, social-intersubjective-being, all in the transcendental sense. Thus, his genetic method made it evident to him that the personal and intersubjective aspect of the ego, which he referred to as a "monad" from 1908 at the latest, is not only a constituted, objective, mundane entity but it is also a constituting agent-like aspect of the concrete transcendental ego. ${ }^{30}$ As we shall see later, this revision of the concept of transcendental ego was strongly and intimately connected with a reinterpretation of the notion of intersubjectivity.

\subsection{Relationship between absolute consciousness, ego and evidence}

Husserl speaks about absolute consciousness and ego in plural at a relatively early stage of his intellectual development (around 1908). According to him, there are several absolute consciousnesses and egos. ${ }^{31}$ In what sense then, are they absolute? They are absolute in the sense that each such absolute consciousness is an absolute point of orientation for each individual subject. This refers to the inevitability of the first-person perspective, and that we cannot breach the epistemological borders of the sphere of our own immanence. Absolute consciousness, and the absolute ego, is an epistemological absolute.

What can be said of absolute evidence within the sphere of immanence, in its relationship to this absolute consciousness? Absolute evidence is an even more particular form, or level, of the Absolute, as absolute givenness of something objective. For Husserl, a predicative insight concerning something objective (an object or state of affairs), accompanied by absolute evidence, is the constitutive element of an apparently incorrigible knowledge. ${ }^{32}$ It is the possession of the absolute ego, but it is also something intersubjectively communicable and verifiable. An incorrigible insight must be shareable and capable of being the subject-matter of intersubjective scrutiny. On the proper level of rational thought, any rational being must be able to understand and verify such an absolute piece of knowledge. It is also of utmost importance that, in Husserl's opinion, the meaning of such absolute predicative insights is always open; that is to say, its meaning is potentially inexhaustible. Every single piece of knowledge, accompanied by absolute evidence, is part of a complex and essentially open web of perpetual cognition that can never be fully captured by an accomplishment of consciousness. Every new piece of information, every new piece of knowledge, sheds new light on earlier insights.

\footnotetext{
29 See: Luft (2011).

${ }^{30}$ Cf. e.g. Husserl (1973b, pp.5-8).

31 Cf. e.g. Husserl (1973b, pp.14ff).

32 At some places Husserl allows the possibility of correction of apodictic evidence. Cf. Husserl (1974, p.164). See also: Heffernan (2009), Berghofer (2018, pp.12f).
} 
Absolute (apodictic) evidence is the lowest, least independent, manifestation of the Absolute as such. If something is really absolutely given then there must be a core of this givenness which is absolutely incorrigible, infallible and inevitable. This absolute givenness is related to the absolute consciousness. Evidence and cognition could receive their more concrete forms, however, only on the intersubjective level.

Absolute ego or consciousness is, at the least, a relatively independent form of the Absolute; this means that we necessarily experience and cognize everything from the first-person perspective, and we can never leave it behind. But on a higher level of cognition, the subject (as absolute ego or consciousness) proves to be a dependent part of an intersubjective community; the ego is proven to be an essentially intersubjective being. Transcendental intersubjectivity is the second main level of the Absolute in Husserl.

\section{Transcendental intersubjectivity: the ontological absolute}

Relatively detailed analyses concerning the problem of intersubjectivity can already be found in Husserl's work in his early work, such as his fairly systematic writing on the topic from around $1908 .{ }^{33}$ It was central to his 1910/11 Winter Semester lecture, The Basic Problems of Phenomenology, and also the second book of Ideas. ${ }^{34}$ It was quite clearly a question of utmost importance for him, within the overall context of phenomenology. Everything - all meaning, validity, evidence, the self, the world, etc.- could be constituted in full concreteness on the intersubjective level. However, he managed to particulate the proper method for unfolding the domain of intersubjectivity in its entire richness and concreteness only in his later period.

Husserl's theory of intersubjectivity can be divided into two significant periods. In the first, intersubjectivity counted as a special field of constituted phenomena. Relative to consciousness, it was a sort of objectivity-though of a very particular sort. In the end, it was about a community of subjects who seemed to be more or less similar. Before the "discovery" of genetic phenomenological method, however, Husserl did not have the proper phenomenological tools to make the other person accessible as a transcendental subject as such. From the standpoint of static phenomenology, the other was approached by Husserl as a mundane psychic subject. The elaboration of genetic phenomenology brought a radical change also in this respect; the transcendental ego proved to be a dependent moment of an infinitely open community of transcendental subjects. ${ }^{35}$

\subsection{Constituted, mundane intersubjectivity}

In the early stage of Husserl's transcendental phenomenology, intersubjectivity was an achievement of the constituting pure ego and it was relative to it. As mentioned

\footnotetext{
33 Cf. Husserl (1973b, pp.3-13; 2014, pp. 137-168).

34 Cf. Husserl (1973b, pp.111-194; 1952).

35 See e.g. Husserl (1992, pp.86f).
} 
earlier, at this time, for Husserl, the pure ego was "completely empty," "without any content" or "any hidden inner richness." 36 Absolute or pure ego was a pure, empty, logical centre, a point of reference for experiences and acts. Intersubjectivity-in Ideas, in 1912 - was a characteristic of the constituted personal ego; other egos, other subjects were relative beings constituted by the pure, absolute ego. One can certainly think of the egos of other human beings as absolute ego-but the ego of others as absolute ego is arguably inaccessible for phenomenological analysis.

The basis of constitution of intersubjectivity and experience of the other (Fremdserfahrung) in Husserl was, first and foremost, empathy (Einfühlung-in some translations also "intropathy") ${ }^{37}$ It is a term that he-in its application to the problem of intersubjective experiences-borrowed from the philosopher and psychologist Theodor Lipps. ${ }^{38}$ Lipps rejected such a conception of empathy, according to which it would be "an analogical inference" ("Analogieschlu $\beta$ ”); he emphasized that empathy is not an active achievement, some explicit hypothetical reconstruction of the inner mental life of the other, but a passive cognitive functioning due to which we can experience the other as other. Husserl fully agrees with this. But he also criticized Lipps for grasping empathy as an empirical-inductive achievement, albeit a passive one-and Husserl could not accept such an interpretation. ${ }^{39}$ Empathy, for Husserl, is a transcendental function of the pure ego or consciousness, due to which it can-passively — constitute another subject, a mundane empirical being who is, nevertheless, similar to it at essential points. Husserl presents his theory of empathy for the first time in a systematic, methodologically conscious way in Ideas II, in 1912. ${ }^{40}$ Empathy, in his opinion, is a passive intentional structure, a passive way of constitution, which enables one to experience and understand the other as other, as a subject similar to oneself. It is an "analogizing apperception." It means that one experiences the other as an "analogy" of oneself; and it is an appresentation or apperception, which means that it is an "indirect" form of intentionality, which can never be entirely fulfilled. It grants a mediate, indirect access to the other, but one cannot experience the inner mental life of the other from one's first person perspective. Later, in Cartesian Meditations, Husserl would say that if he could experience the other person's mental sphere directly, then "he himself and I myself would be the same." 41

According to Husserl, the experience of body plays a crucial role in the functioning of empathy. Without a body, I would be incapable of empathy. The lived body (Leib), as well as externally experienced physical body (Körper), in Husserl's view, is the phenomenological basis of empathy. Body is a precondition of the functioning of empathy. I experience the body of the other as similar to mine. It is the basis of analogizing apperception. The body of the other is always "there," and mine is

\footnotetext{
${ }^{36}$ Husserl (1976, p.179; 1952, p. 105).

37 See: Steinbock (1995, p. 52).

38 Lipps (1909).

39 Husserl (1973b, pp. 23f, 74). See also: Makkreel (1996, especially: p. 199f).

40 Husserl (1952, p. 167-172, 228f, 347).

41 Husserl (1960, p. 109), German original: (1973a, p. 139).
} 
always "here;" my body is an absolute here. I experience the other's body necessarily and always from the "outside," externally, as a physical body, but the similarity and analogy of my body and the other motivates me to apperceive his/her body as having an inner aspect; that is to say, I conceive his/her body as a "psychophysical unity," as an inseparable unity of psychic and physical, of Leib and Körper. The experience of the other person's body motivates the empathy towards the other; it motivates me to experience him or her as somebody whose physical body has an internal aspect, who is another experiencing subject just like me. He/she also experiences joy or pain, hope or despair, curiosity or boredom etc., just like me.

Although in this period, the body is a constituted entity for Husserl, it has a central role in every other form and region of constitution. According to him, the constitution of the body fundamentally determines the constitution of space, objects, other persons and the world as such. In this way, the relationship between the constitution of self, other and the world is circular; they mutually determine each other's constitution. $^{42}$

In this period, Husserl could only thematize the phenomenon of intersubjectivity in a phenomenologically adequate manner as a sphere of mundane, constituted, empirical appearances. The discovery of genetic method led to a fundamental deepening and refinement of his earlier approach of intersubjectivity.

\subsection{Constituting, transcendental intersubjectivity}

Husserl started to unfold the principles and rules of apriori, transcendental genesis in a systematic way around 1916/17. "Finding" the genetic method altered Husserl's philosophy in its fundaments; it widened its scope incredibly, it enabled Husserl to make clarifications and specifications that were not previously feasible, and it made accessible, in a phenomenologically legitimate manner, problems and topics which earlier were not. Some authors, such as Nam-In Lee or Alexander Schnell, rightly claim that the unfolding of genetic method was as important a novelty in Husserl's career as the finding of the transcendental reduction. ${ }^{43}$

The genetic approach showed the transcendental ego as being not merely a logical, formal pole of acts and experiences, but also as a concrete, content-rich subject, who is a historical, social and cultural being, even under the phenomenological reduction. Genetic phenomenology refers partly to "monadic genesis," when the transcendental ego appears as a concrete, personal agent in transcendental regard, who has a transcendental history, and also possesses many abilities, habitualities and sedimentations. In this regard, the ego cannot be treated otherwise as a co-subject of other transcendental egos. Genetic phenomenology shows an internal connection between transcendental egos; it can unfold my own transcendental ego as part of an infinitely open intersubjective, intermonadic community. Transcendental egos appear, as it were, in an "intentional being-in-each-other" ("intentionale

\footnotetext{
42 Cf. Zahavi (1994).

43 Lee (1993, pp. 17-30). Schnell (2007, p. 201).
} 
Ineinander"); for the genetic approach, the concrete transcendental ego cannot appear as other than intersubjective, in the transcendental sense of the word. ${ }^{44}$

As a result of this radical and drastic widening of the scope and depth of transcendental phenomenology, Husserl in the 1920s started to discuss "transcendental sociology," a transcendental-phenomenological theory of communities. ${ }^{45}$ The transcendental ego appeared as a transcendental person, who has a lived body (Leib), history, culture and community - all these in the transcendental sense. Transcendental intersubjectivity is the open community of such transcendental persons; in the end, however, it is not only a community of human, rational subjects, but also the community of every subject whatsoever, human or not, thus including animals when treated from the transcendental point of view.

From the standpoint of genetic phenomenology, the process and achievement of constitution proved to be a collective activity from the very outset. As an intersubjective being and part of a community, I constitute the different essential types and regions of objects.

On the level of transcendental intersubjectivity, the solipsistic conception of the ego appeared to be a necessary methodological abstraction, which, nonetheless, must be necessarily overcome. Solipsism, as Husserl says, is only "a transcendental illusion." ${ }^{46}$ I am, as a transcendental subject, a dependent moment of an intersubjective community; I do not have a concrete, independent being apart from it.

I, as a transcendental person, have a body, a culture, a history, etc. as a dependent moment of this community. Even such characteristics of my transcendental being gain their more concrete, deeper meaning as part of the transcendentally intersubjective community, as dependent moments of its collective corporeality, culture and history. ${ }^{47}$ All these structural features have their concrete meaning within the overall context of a transcendental community; my related particular features and structures (the concrete transcendental meaning of my corporeality, cultural, social and historical being, etc.) could be interpreted in the more general context of the transcendental intersubjective community, of which I am a dependent part.

Husserl referred to the theory of intersubjectivity in the 1920 s as "absolute" or "transcendental ontology." 48 Transcendental ontology, as the theory of transcendental intersubjectivity, is, for Husserl, the ultimate context of all empirical and transcendental—philosophical science and knowledge.

The objective being is relative to this constituting and ultimately functioning, absolutely open transcendental intersubjectivity. On this level, universal transcendental intersubjectivity proves to be the final source of every meaning and validity, the validity of all norms and objectivities. For this reason,

\footnotetext{
44 Husserl (1973d, pp. 371-377).

45 Husserl (1966, p.220) (1968, p.539) (2006, p.165). See also: Zahavi (1996), Ferrarello (2012).

46 Husserl (1974, p. 248f).

47 Regarding collective corporeality: "The»We« has its collective corporeality" —said Husserl in a manuscript from 1932. ("Das Wir hat seine kollektive Leiblichkeit") (2008, p.181).

48 Husserl (1959, pp. 212ff).
} 
transcendental intersubjectivity is unveiled for Husserl as the ultimate ground of being (Seinsboden). ${ }^{49}$

\subsection{Metaphysics of experience or metaphysical neutrality?}

For those philosophers who would like to keep themselves away from theologically oriented speculations and speculative metaphysics in general, this conception of phenomenology, which conceives of the Absolute as constituting transcendental intersubjectivity, was and still is arguably the most promising, most fruitful philosophical method. This intersubjective approach of makes accessible an immensely rich field of experiential analyses, also integrating the findings of contemporary phenomenological investigations in a strictly scientific manner.

It is an unlimited workspace of concrete experiences, which offers us two avenues for autonomous continuation and innovative practice of phenomenology within the contemporary cultural and philosophical context: (1) phenomenological metaphysics as a metaphysics of experience, which is a break from classical, traditional, speculative metaphysics, and (2) a metaphysically neutral or quasi-neutral analysis of experiences.

One of the best examples for the first stance is the philosophy of László Tengelyi $(† 2014) .{ }^{50}$ It is the attempt to realize phenomenological metaphysics as a metaphysics of experience, perpetually taking into consideration recent scientific discoveries and the results of contemporary non-phenomenological philosophical endeavours with intention of dialogue. This conception of phenomenological metaphysics as a metaphysics of contingency-according to Tengelyi-has especially deep roots in the French phenomenological tradition, amongst others, in the philosophy of Sartre, Merleau-Ponty, Lévinas, Richir and Marion. ${ }^{51}$

The second approach is metaphysically less committed, or even intentionally and explicitly neutral (or at least quasi-neutral), in metaphysical regard. Amongst other authors, Jeff Yoshimi argues that Husserl's philosophy is basically neutral in metaphysical respect, in the sense that it is "compatible with multiple metaphysical frameworks (including frameworks Husserl argued against). ${ }^{, 52}$ In Yoshimi's interpretation, phenomenology, and in particular, Husserlian phenomenology, is a rich analysis of intersubjectively shaped experiences. Metaphysics is the science of ultimate reality, just as Husserl thought. ${ }^{53}$ There could be a connection, even a fruitful dialogue, between them, but they are not identical. Yoshimi proposes a "division of labour" between these two. ${ }^{54}$

So, according to the second conception concerning the fundamental tasks and aims of phenomenology, it is a less metaphysically engaged philosophical work on

\footnotetext{
49 Husserl (1968, p. 294f).

50 Tengelyi (2014). See also: Römer (2017).

51 Cf. Tengelyi (2014, pp. 264-294).

52 Yoshimi (2015, p. 1).

53 See, amongst others: Bernet etal. (1996, pp. 209-213). See also: Zahavi (2017, pp. 48-50).

54 Yoshimi (2015, p. 13).
} 
experiences and experiential structures, emphasizing the intersubjective dimension of analyses. This viewpoint and attitude to phenomenology is found, amongst others, in Jocelyn Benoist, Dan Zahavi, David Carr and Dieter Lohmar. ${ }^{55}$

But Husserl did not want to limit his phenomenology to a structural analysis of experience; he also had some higher ambitions. He thought that phenomenology, on the highest level, must also address the "ultimate" and "highest" questions. ${ }^{56} \mathrm{He}$ also wanted to raise speculative metaphysical questions concerning the immortality of soul and the existence of God. That is to say, he wanted to treat theologically relevant questions with the method of phenomenology. For phenomenology, however, "the ultimate source of all legitimate knowledge is originally giving intuition." 57 Such speculative metaphysical problems exceed the boundaries of possible intuition in a rather obvious way. How Husserl thought it was possible to handle such questions in a phenomenologically legitimate manner is described in Part III.

\section{God. The metaphysical absolute}

Husserl himself stated more than once that, throughout his entire career, the problem of God was always of central importance for him. Among a number of other testimonies, in a letter to his student and friend Arnold Metzger, dated 4 September 1919, he wrote: “... The New Testament had such an enormous influence on that 23-year-old, which urged him to find a way to God and true life through the method of a strictly philosophical science." ${ }^{58}$ Also, in his late manuscripts from the 1930s, he dealt with the problem of God; most prominently in the E-Manuscripts. As Stephan Strasser stated, "Husserl as a man and philosopher struggled with the problem of God throughout his entire life." 59

On closer inspection, the problem of God was always at the core of Husserl's work. ${ }^{60}$ God signified the ultimate goal of his philosophical and metaphysical endeavors; it was the highest level and form of Absolute, the final aspect of reality. In the end, it was the key to the "ultimate" and "highest" questions. God, as we shall see soon, entailed the concrete singular of transcendental egos, and the infinite transcendental intersubjectivity, as dependent, non-autonomous layers of His reality. What is even more intriguing in Husserl is that the circularity, that we can find on lower levels of the Absolute, can be found on the highest (divine) level too.

\footnotetext{
55 In this context I would like to draw attention especially to the essay of Dan Zahavi on Husserl's notion of the Absolute, where Dan Zahavi interprets this notion in a less metaphysically committed way, conceiving it first and foremost as the constituting functioning of transcendental intersubjectivity, emphasizing the importance of dialogue with other philosophical traditions and positive sciences. See: Zahavi (2010, especially: p. 87ff).

56 Husserl (1973a, p.182; 1968, pp.299ff).

57 Husserl (1976, p.51).

58 "[O]n that 23-year-old"-Id est: in 1882. Husserl (1994, p.408).

59 Strasser (1959, p. 130).

60 See: Lo (2008). Also: Held (2010).
} 
In a certain manner, God proves to be dependent on the lower levels, and yet the moments of God's existence are also strongly intertwined with Him.

\subsection{Phenomenological construction and the idea of God}

The question should be raised again: how did Husserl hope to thematize the problem of God in a phenomenologically adequate and legitimate manner, when God obviously lies beyond the borders of possible intuition? In brief, how would this be possible through phenomenological constructions. It is well known that Husserl was very critical of the method of constructions. He sometimes juxtaposed phenomenological constitutions to non-phenomenological constructions. He regarded construction as a basically illegitimate and inadequate operation. ${ }^{61}$ But he also had the idea of the phenomenologically legitimate constructions which are phenomenologically motivated. ${ }^{62}$ Long before Eugen Fink's Sixth Cartesian Meditation (1932), Husserl had already formed the idea of phenomenologically legitimate constructions, in some of his research manuscripts and lectures from the years 1907-1914. ${ }^{63}$

How is this phenomenological method supposed to work? According to Husserl, within the sphere of evident phenomenological givenness, there could be signs and indications which point beyond the borders of possible intuition; signs and indications which could never be entirely fulfilled, but which could be followed beyond the realm of evident givenness. Such signs and indications could motivate a transgress in a phenomenologically legitimate manner. Husserl speaks about "the logic of metaphysical motivation." ${ }^{4}$ We are motivated to construct the invisible and that which, for theoretical reasons, cannot be seen at all, but we can do it in a phenomenologically justified way.

One could argue about whether or not this method of phenomenological construction is really justified, whether it is a necessary consequence and implication of the movement of phenomenological analysis indeed, and whether it is mere, nonphenomenological speculation. ${ }^{65}$ In Husserl's opinion, however, one simply cannot renounce the duty to raise the question concerning the ultimate form of reality, which also entails the question of the being of God. In his view, it would be a

\footnotetext{
61 Husserl (1973a, p.36).

62 Husserl (1973a, p.37).

63 Manuscript B I 4 (1908): unpublished. B II 2: Husserl (1973b, pp.5-9) (2014, pp.137-168). “Lectures on ethics and value theory, 1908-1914" (1988).

To the relationship between Fink and Husserl see e.g. Varga (2011).

64 Husserl (2014, p.164). We must add, that here Husserl also mentions "the ideal possibility of fulfilment." But in this case we should emphasize that we are speaking about "ideal possibilities."

65 We can find such a negating opinion in Vittorio De Palma, who-in his 2019 article-explicitly and emphatically rejects that phenomenological construction would be a legitimate method of phenomenology. He considers it to be an abandonment of phenomenology; he is of the opinion that phenomenology and metaphysics are two, completely different fields, which are entirely alien to each other.

This conception refers back to the second standing point, the second main interpretation of phenomenology (and thus: phenomenological Absolute), that we have treated in the previous section of our paper: so a metaphysically neutral, descriptive analysis of the objects and structures of experience. See: De Palma (2019).
} 
capitulation to abandon the inquiry concerning the metaphysical Absolute; it would be a gesture which meant leaving philosophy itself behind. To raise a question like that is one of the highest duties of a philosopher. It is an imperative. Phenomenological construction was one of his main philosophical means by which to thematize the metaphysical Absolute in a phenomenologically grounded way. ${ }^{66}$

How did Husserl actually use phenomenological constructions to make God phenomenologically accessible? Two essential points in this project were the elaboration of a universally unified theory of phenomenological constitution and his "discovery" of transcendental idealism after 1905.

First, after 1905, alongside with his "transcendental turn," he deepened and widened his theory of constitution. Constitution, for him, was the capacity of consciousness to afford meaning, validity and value to phenomena. It was due to this capacity that consciousness could experience any objectivity whatsoever. Second, Husserl connected his idea of constitution with the recently fleshed out conception of transcendental idealism. In a manuscript, written in June 1913, he wrote that the very idea of an actually existing thing also prescribes the actual existence of a consciousness. ${ }^{67}$ He claimed that this connection is necessary in order to secure that a concrete thing could be constituted in its entirety, in a fully harmonious and rational way.

Husserl also made a further step. He thought that, in order to ensure the entire objectivity and rationality of the world as such, we need much more than a single transcendental subject; we need even more than a universal community of transcendental subjects. Even the collective constitutive activity of such a community would be fragmentary and arbitrary, and thus insufficient to warrant the fully complete and coherent objectivity and rationality of reality.

In order to be able to be constituted in a completely coherent, harmonious and rational way, the idea of an infinitely rich and complex reality-in his view-prescribes the idea of an infinite and universal subject, who can constitute this world in its entire richness and complexity. Thus, Husserl linked the conception of a universally unified and coherent form of constitution with the above-mentioned thesis of transcendental idealism; the idea of an infinite world, which is implicated in the universally open horizontality of experiences, prescribes the idea of an infinite subject.

In a dynamic and temporal regard, I experience the world in perpetual development. This development-in the natural as well as the cultural world-is constituted in a teleological order. Such a teleological order, and the concrete, specific teleologies that it entails, points toward an ideal fulfilment, a fulfilment of absolute

\footnotetext{
66 George Heffernan, however, at a conference in 2019 treats another way to God in Husserl, (Grenzprobleme der Phänomenologie. Second Research Summer School in Genetic Phenomenology. Warsaw, Poland. Graduate School for Social Research, Institute of Philosophy and Sociology, Polish Academy of Science. 2-6 September 2019).

According to Heffernan, the idea of God in Husserl could also be a result of a systematic self-reflection and reflection to the world (Selbstbesinnung, Weltbesinnung) — in a rather Kantian way, as an existential motif, as a result or product of rational belief, within a practical-ethical framework. In Husserl: (2014, pp. 487-490, 515-517). Heffernan (2019).

67 Husserl (2003, p.77).
} 
perfection that lies in infinity. Through phenomenological construction, I can complete in thought the teleologies that I experience in the world and, according to Husserl, I can construct, in a phenomenologically legitimate manner, the ultimate endpoint of such teleologies, namely, God Himself.

Taken as actual reality, God appears in phenomenological reflection as the innermost engine of every teleology, every development in the world. He keeps the world in progress, and governs the processes and courses towards their aims.

\subsection{God as person}

God, in Husserl's interpretation, is not just an ideal, but also an actually existing person. God has an ideal but also a personal character. He is a person who experiences the world Himself in a universal way, but also through the particular, individual perspective of finite subjects. He has first-person access to the experiences and thoughts of finite beings. As Husserl says, God "experiences every suffering, every misfortune, and every mistake" of the finite creatures Himself from the first-person perspective. ${ }^{68}$ God is infinite compassion in regard of every single being.

In some places, Husserl refers to God as the Supreme Monad (Übermonade), the Highest Person and Consciousness. He resides in the inner mental life of every finite, particular monad; $\mathrm{He}$ is the inherent, intrinsic, structural implication of their subjectivity; He is immanent, yet compared to them also transcendent. ${ }^{69} \mathrm{God}$, according to Husserl, has a quite paradoxical structure; He is immanent and transcendent to transcendental (inter)subjectivity at the same time. The paradoxical features of God are understandable, because we try to thematize an infinite being from our finite, limited point of view, with a necessarily limited conceptual apparatus. But at least there are some conceptual points and structures concerning God which we can understand, and, in Husserl's opinion, through the history of phenomenology, we can comprehend Him more and more. Similar to the cognition of the world, the cognition of God is also an infinite, open project, which means an infinite approach.

God, for Husserl, proves to be the ultimate form of the Absolute, the highest aspect and level of reality, Who entails and unifies in Himself the lower levels of the Absolute, the singular transcendental egos and the unlimited horizon of transcendental intersubjectivity as His dependent moments, which are abstract apart from Him. For the first instance, it seems that transcendental intersubjectivity is a dependent layer in the divine life of God. But, according to some of Husserl's manuscripts Husserl, there is an even more complicated relationship between God and transcendental intersubjectivity. In a manuscript from 5 November 1931, Husserl claims that

\footnotetext{
${ }^{68}$ Husserl (2014, p.168). "Of course we should not think of this universal I-who embraces every I-s and reality in himself_-as an empirical I. He is infinite life, infinite love and infinite will. His infinite life is the only activity; and because he is infinite fulfilment, he is also infinite happiness. God himself also experiences every suffering, every misfortune, every mistake; and only because he lives in others, and he feels with others, can he overcome his finitude, his not-necessary-being in the infinite harmony, for which he exists. God is everywhere, God's life lives in every life." My translation-[The author].

69 Husserl (1973c, pp. 300-302).
} 
God, in turn, also presupposes the being of transcendental intersubjectivity for His more concrete being. ${ }^{70}$ Accordingly, there is a mutual dependence, an intertwined or entangled correlation between God and transcendental intersubjectivity. What is that supposed to mean?

If I understand the train of thought from the cited manuscript correctly, Husserl states that the infinite and also the finite belong to the full constitution of the world. God could experience and constitute the world in its entirety, in its infinite richness, if He has access also to the finite constitutive modes of the singular transcendental subjects and their intersubjective community. Finite and infinite modes of constitution together make possible the fully concrete, coherent appearance of the world. Without transcendental (inter)subjectivity, God would not be able to experience and constitute the world fully concretely; in this sense, He presupposes it.

According to Husserl, God, as a person, as the Highest Person, is also a member, a moment of the organic entanglement of the universal community of transcendental subjects; as an infinite person, as the infinite aspect of transcendental intersubjectivity, $\mathrm{He}$ is also a person self.

\subsection{The radical novelties of Husserl's notion of the Absolute}

As we claimed in the Introduction of this paper, Husserl's notion of the Absolute is, at some points, radically new, and could be very fruitful for contemporary debates in philosophy. It is a non-foundational Absolute, the essential characteristics of which are circularity, contextuality and openness.

Husserl makes good use of his theory of mutual foundation of contents, which he elaborated in Logical Investigations, at every level of his interpretation of the absolute. On the first level, there is a circular connection of the contents of absolute ego and its self-constitution. These contents determine the particular way of self-constitution of the ego, which, in turn, also determines the way the ego constitutes the presented contents. On the second level, each singular transcendental ego determines the entire transcendental community, which, on the other hand, also determines each single ego. Finally, on the third level, God as the ultimate form of the Absolute presupposes the entire transcendental intersubjectivity, which, in turn, also presupposes the existence of God.

Each of these fields offers a promising workspace for philosophical analysis of experience. However, in regard to the third level, there is an important question. In

\footnotetext{
70 Husserl (1973d, p.381). "The universal absolute will, which lives in all transcendental subjects and which makes the individual-concrete being of transcendental All-subjectivity possible, is the divine will; which, however, presupposes the entire intersubjectivity, not as something which precedes it, which could be possible without it (so, not as the soul presupposes the body), but as a structural layer, without which this will cannot be concrete." My translation-[The author].
} 
his 1991 writing on The Theological Turn of French Phenomenology, Dominique Janicaud states that the theological application of phenomenology demands a fundamental shift in methodology, which leads us beyond the limits of phenomenology. ${ }^{71}$ By unfolding the structure of the "logical of metaphysical motivation" and showing what is implicated in it, the carefully applied method of phenomenological construction could, in my opinion, be an appropriate means of keeping the philosopher within the borders of legitimate phenomenological investigation. ${ }^{72}$

\section{Conclusion}

In this paper, I tried to show that the final aim of Husserl's phenomenology was to grant philosophical, strictly scientific, access to the ultimate form of reality, to the Absolute as such. In his interpretation, the ultimately concrete reality is the Absolute, and philosophy must thematize it one way or another.

In Husserl's thought, there are different levels of the Absolute; the word "absolute" can be used in several, most importantly three, different, but equally legitimate and systematically interrelated ways. Each of the three ways delineates a relatively independent, entirely justified method and sphere of investigation for phenomenology.

The first level is the absolute consciousness of the individual subject, which is an epistemological absolute. I cannot get rid of my first-person perspective. This first level is already a proper and completely legitimate working area for the phenomenological analysis of subjective experiences.

A consequent and careful phenomenological analysis of such subjective experiences necessarily leads, at a certain point, to the disclosure or "discovery" of the intersubjective dimension. I must face the fact that I can constitute myself, the things and the world itself in a more comprehensive way as part of an intersubjective community. Things gain their proper, more adequate and concrete meaning within the horizon of intersubjective constitution. I am, on a more concrete level, a dependent part of the transcendental intersubjectivity, which can be called the ontological absolute. It is the second level of the Absolute. It could be a promising and fruitful field of philosophical analyses oriented towards intersubjectively shaped experiences: analyses which seek dialogue with contemporary analytic philosophy and positive sciences.

There is, however, a third level. According to Husserl, we might as well give up "philosophy" if we give up aiming to answer the "ultimate and highest" questions of metaphysics. Husserl hoped to answer such questions (first of all, the question concerning the existence of God) through the method of phenomenological construction, through which phenomenology could reach beyond the limits of intuitive accessibility. God, for Husserl, was the absolute foundation of every being whatsoever, and thus the highest level of the Absolute.

\footnotetext{
71 Janicaud (1991).

72 Husserl (2014, p.164).
} 
In Husserl's interpretation, the most concrete form of reality can be phenomenologically reconstructed by presupposing the idea of God, who can constitute reality in its most concrete, infinitely rich and complex form. Phenomenology is an infinite approach to an ever deeper, more precise and concrete understanding of God, and also to the ultimate form of objective reality which is related to God. Even the individual concrete ego and the universal community of ego could be understood in a more concrete way as dependent parts or moments of God.

Funding Open access was funded by Budapest Business School. The study was also supported by the Hungarian Academy of Sciences (Magyar Tudományos Akadémia), by the János Bolyai Research Scholarship of the Hungarian Academy of Sciences (project: BO/00421/18/2) and by the No. 138745 project of Hungarian Scientific Research Fund.

\section{Declarations}

Conflict of interest The authors declare that they donot have any conflict of interest.

Open Access This article is licensed under a Creative Commons Attribution 4.0 International License, which permits use, sharing, adaptation, distribution and reproduction in any medium or format, as long as you give appropriate credit to the original author(s) and the source, provide a link to the Creative Commons licence, and indicate if changes were made. The images or other third party material in this article are included in the article's Creative Commons licence, unless indicated otherwise in a credit line to the material. If material is not included in the article's Creative Commons licence and your intended use is not permitted by statutory regulation or exceeds the permitted use, you will need to obtain permission directly from the copyright holder. To view a copy of this licence, visit http://creativecommons.org/licen ses/by/4.0/.

\section{References}

Berghofer, Philip. 2018. Why husserl is a moderate foundationalist. Husserl Studies 34(1): 1-23.

Rudolf, Bernet, Kern Iso, and Marbach Eduard. 1996. Edmund Husserl. Darstellung seines. Hamburg: Denkens.

Bernstein, Richard J. 1983. Beyond objectivism and relativism: Science, hermeneutics, and Praxis. Philadelphia: University of Pennsylvania Press.

Boehm, Rudolf. 1959. Zum Begriff des "Absoluten" bei Husserl. Zeitschrift für philosophische Forschung, Bd. 13, H. 2, Erweitertes Heft zum 100.Geburtstag von Edmund Husserl. pp. 214-242.

De Palma, Vittorio. 2019. Deskription oder Konstruktion? Husserl und die Grenzen der Phänomenologie. Husserl Studies 35: 185-202.

Drummond, John. 1990. Husserlian intentionality and non-foundational realism. Dordrecht: Kluwer Academic Publishers.

Ferrarello, Susi. 2012. Husserl's theory of intersubjectivity. Cultura 9 (2): 163-174.

Føllesdal, Dagfinn. 1988. Husserl on evidence and justification. In Edmund Husserl and the phenomenological tradition, ed. Robert Sokolowski, 107-129. Washington, D.C.: The Catholic University of America Press.

Heffernan, George. 1999. A study in the sedimented origins of evidence: Husserl and his contemporaries engaged in a collective essay in the phenomenology and psychology of epistemic justification. Husserl Studies 16: 83-181.

Heffernan, George. 2009. On Husserl's Remark that “"[s]elbst eine sich als apodiktisch ausgebende Evidenz kann sich als Täuschung enthüllen ..." (XVII 164:32-33): Does the phenomenological method yield any epistemic infallibility. Husserl Studies 25: 15-43. 
Heffernan, George. 2019. Universal besinnung or selbstbesinnung: husserl's method for the treatment of ethical, existential, and metaphysical questions as grenzprobleme of phenomenology. Hyperlink: https://www.memphis.edu/philosophy/opo2019/pdfs/heffernan-george.pdf. Accessed: 15 May 2020.

George, Heffernan. 2021. Truth and evidence. In The Routledge Handbook of Phenomenology and Phenomenological Philosophy, ed. Daniele de Santis, Burt Hopkins, and Claudio Majolino, 412-424. London \& New York: Routledge.

Held, Klaus. 1966. Lebendige Gegenwart: Die Frage nach der Seinsweise des transzendentalen ich bei Edmund Husserl, entwickelt am Leitfaden der Zeitproblematik. The Hague: Martinus Nijhoff.

Held, Klaus. 2010. Gott in Edmund Husserls Phänomenologie. In Philosophy, phenomenology, sciences. Essays in commemoration of Edmund Husserl, ed. Carlo Ierna, Hanne Jacobs, and Filip Mattens, 723-738. Dordrecht: Springer.

Hopp, Walter. 2008. Husserl, phenomenology, and foundationalism. Inquiry 51: 194-216.

Husserl, Edmund. 1925. Phänomenologische Psychologie. Vorlesungen Sommersemester. 1925. The Hague: Martinus Nijhoff.

Husserl, Edmund. 1950. Die Idee der Phänomenologie Fünf Vorlesungen. The Hague: Martinus Nijhoff.

Husserl, Edmund. 1952. Ideen zur einer reinen Phänomenologie und phänomenologischen Philosophie. Zweites Buch: Phänomenologische Untersuchungen zur Konstitution. The Hague: Martinus Nijhoff.

Husserl, Edmund. 1959. Erste Philosophie (1923/4) Zweiter Teil: Theorie der phänomenologischen Reduktion. The Hague: Martinus Nijhoff.

Husserl, Edmund. 1960. Cartesian meditations (Trans: Cairns, D). The Hague: Martinuf Nijhoff.

Husserl, Edmund. 1966. Analysen zur passiven Synthesis. Aus Vorlesungs- und Forschungsmanuskripten, 1918-1926. The Hague: Martinus Nijhoff.

Husserl, Edmund. 1969. Zur Phänomenologie des inneren Zeitbewusstesens (1893-1917). The Hague: Martinus Nijhoff.

Husserl, Edmund. 1973a. Cartesianische Meditationen und Pariser Vorträge. The Hague: Martinus Nijhoff.

Husserl, Edmund. 1973b. Zur Phänomenologie der Intersubjektivität. Texte aus dem Nachlass. Erster Teil. 1905-1920. The Hague: Martinus Nijhoff.

Husserl, Edmund. 1973c. Zur Phänomenologie der Intersubjektivität. Texte aus dem Nachlass. Zweiter Teil. 1921-28. The Hague: Martinus Nijhoff.

Husserl, Edmund. 1973d. Zur Phänomenologie der Intersubjektivität. Texte aus dem Nachlass. Dritter Teil. 1929-35. The Hague: Martinus Nijhoff.

Husserl, Edmund. 1974. Formale and transzendentale Logik. Versuch einer Kritik der logischen Vernunft. The Hague: Martinus Nijhoff.

Husserl, Edmund. 1976. Ideen zu einer reinen Phänomenologie und phänomenologischen Philosophie. Erstes Buch: Allgemeine Einführungin die reine Phänomenologie 1. The Hague: Martinus Nijhoff.

Husserl, Edmund. 1983. Ideas Pertaining to a Pure Phenomenology and to a Phenomenological Philosophy, FirstBook. General Introduction to a Pure Phenomenology. Translated by Fred Kersten. Dordrecht: Kluwer AcademicPublishers.

Husserl, Edmund. 1985. Einleitung in die Logik und Erkenntnistheorie. Vorlesungen 1906/07. The Hague: Martinus Nijhoff.

Husserl, Edmund. 1988. Vorlesungen über Ethik und Wertlehre. 1908-1914. The Hague: Kluwer Academic Publishers.

Husserl, Edmund. 1992. Die Krisis der europaischen Wissenschaften und die transzendentale Phänomenologie. Ergänzungsband. Texte aus dem Nachlass 1934-1937. The Hague: Kluwer Academic Publishers.

Husserl, Edmund. 1994. Briefwechsel. Band IV: Die Freiburger Schüler. Dordrecht: Kluwer Academic Publishers.

Husserl, Edmund. 2003. Transzendentaler Idealismus Texte aus dem Nachlass (1908-1921). Dordrecht, Netherlands: Kluwer Academic Publishers.

Husserl, Edmund. 2006. Späte Texte über Zeitkonstitution (1929-1934). Die C-Manuskripte. New York: Springer.

Husserl, Edmund. 2008. Die Lebenswelt. Auslegungen der vorgegebenen. Welt und ihrer Konstitution. Texte aus dem Nachlass (1916-1937). New York: Springer.

Husserl, Edmund. 2012. Zur Lehre vom Wesen und zur Methode der eidetischen Variation. Texte aus dem Nachlass (1891-1935). New York: Springer.

Husserl, Edmund. 2014. Grenzprobleme der Phänomenologie. Analysen des Unbewusstseins und der Instinkte. Metaphysik Späte Ethik (Texte aus dem Nachlass 1908-1937). New York: Springer. 
Janicaud, Dominique. 1991. Le tournant théologique de la phénoménologie française. Paris: Éditions de l'Éclat.

Lee, Nam-In. 1993. Edmund Husserls Phänomenologie der Instinkte. Dordrecht: Kluwer Academic Publishers.

Lee, Nam-In. 2007. Experience and evidence. Husserl Studies 23: 229-246.

Lipps, Theodor. 1909. Leitfaden der Psychologie. Leipzig: Wilhelm Engelmann Verlag.

Lo, Lee Chun. 2008. Die Gottesauffassung in Husserls Phänomenologie. Frankfurt am Main: Peter Lang.

Luft, Sebastian. 2011. Husserl's Concept of the 'Transcendental Person'. Another look at the HusserlHeidegger relationship. Subjectivity and Lifeworld in Transcendental Phenomenology, pp. 126-158. Evanston, Illinois: Northwestern University Press.

Makkreel, Rudolf A. 1996. How is empathy related to understanding? In Issues in Husserl's ideas II, ed. Thomas Nennon and Lester Embree, 199-212. Dordrecht: Kluwer Academic Publishers.

Marosan, Bence Peter. 2020. Husserl's contextualist theory of truth. Horizon 9: 162-183.

Dermot, Moran. 2003. Making sense: Husserl's phenomenology as transcendental idealism. In From Kant to Davidson philosophy and the idea of the transcendental, ed. Jeff Malpas, 48-74. London \& New York: Routledge.

Rorty, Richard. 1979. Philosophy and the mirror of nature. Princeton: Princeton University Press.

Römer, Inga. 2017. Was ist phänomenologische Metaphysik? In Welt und Unendlichkeit. Ein deutschungarischer Dialog in memoriam László Tengelyi, ed. Markus Gabriel, Csaba Olay, and Sebastian Ostritsch, 115-130. Freiburch/München: Karl Alber.

Schnell, Alexander. 2007. Husserl et les fondements de la phénoménologie constructive. Grenoble: Éditions Jérôme Millon.

Sokolowski, Robert. 1970. The Formation of Husserl's Concept of Constitution. The Hague: Martinus Nijhoff.

Steinbock, Anthony. 1995. Home and beyond. Generative phenomenology after husserl. Evanston: Northwestern University Press.

Strasser, Stephan. 1959. Das Gottesproblem in der Spätphilosophie Edmund Husserls. In Philosophisches Jahrbuch der Görresgesellschaft, 67. Jg., Freiburg/München: Alber, pp. 130-142.

Taguchi, Shigeru. 2006. Das Problem des ,Ur-Ich' bei Edmund Husserl. Die Frage nach der selbstverständlichen ,Nähe’ des Selbst. Dordrecht: Springer.

Tengelyi, László. 2014. Welt und Unendlichkeit Zum Problem phänomenologischer Metaphysik. Freiburg/ München: Karl Alber.

Varga, Péter András. 2011. The architectonic and history of phenomenology: Distinguishing between Fink's and Husserl's notion of phenomenological philosophy. In Phenomenology Selected Essays from Northern Europe, vol. 4, ed. Dermot Moran and Hans-Reiner. Sepp, 87-114. Bucharest: Zeta Books.

Yoshimi, Jeffrey. 2015. The metaphysical neutrality of husserlian phenomenology. Husserl Studies 31: $1-15$.

Zahavi, Dan. 1994. Husserl's phenomenology of the body. Études Phénoménologique 19: 63-84.

Zahavi, Dan. 1996. Husserl und die transzendentale Intersubjektivität. Eine Antwort auf die sprachpragmatische Kritik. Dordrecht: Kluwer Academic Publishers.

Zahavi, Dan (2003). Husserl's Phenomenology. Stanford: Stanford University Press.

Zahavi, Dan. 2010. Husserl and the "absolute." In Philosophy, phenomenology, sciences. Essays in commemoration of Edmund Husserl, ed. Carlo Ierna, Hanne Jacobs, and Filip Mattens, 71-92. Dordrecht: Springer.

Zahavi, Dan. 2017. Husserl's legacy phenomenology, Metaphysics, and transcendental philosophy. Oxford: Oxford University Press.

Publisher's Note Springer Nature remains neutral with regard to jurisdictional claims in published maps and institutional affiliations. 